\title{
$45 \mathrm{kG}$ 鞍形超電導電磁石（その 1 )
}

一一電磁石, クライオスタット, 総合運転—

木 村 浩* ・土井俊 雄* - 佐 藤 新太郎*

笠原 達 雄 ${ }^{* *}$ ・飯塚 富 雄***

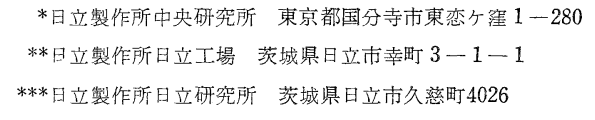

(1970年 3 月 4 日受理)

$45 \mathrm{kG}$ Saddle Shaped Superconducting Magnet, Part 1

Magnet, Cryostat \& Their Test Results-_

Hiroshi Kimura*, Toshio Dor*, Shintaro Sato*, Tatsuo

KASAHARA**, and Tomio IIzUKA***

\footnotetext{
*Central Research Laboratory, Hitachi, Ltd., 1-280 Higashikoigakubo, Kokubunji, Tokyo

**Hitachi Works, Hitachi, Ltd., 3-1-1 Saiwai-cho, Hitachi-shi, Ibaragi-ken

***Hitachi Research Laboratory, Hitachi, Ltd., 4026 Kuji-machi, Hitachi-shi, Ibaragi-ken
}

(Received March 4, 1970)

A large saddle shaped superconducting magnet was built and tested.

The conductor used was a composite consisting of $0.7 \mathrm{~cm}$ wide by $0.16 \mathrm{~cm}$ thick copper strip in which ten $\mathrm{Nb}-40 \mathrm{Zr}-10 \mathrm{Ti}$ (HISUPER X-alloy) wires were embedded in two rows. The physical characteristics of the magnet were as follows : winding inside diameter, $38 \mathrm{~cm}$; winding outside diameter, $88 \mathrm{~cm}$; overall length, $180 \mathrm{~cm}$. A cryostat to contain the coil had a room temperature space $(25 \mathrm{~cm}$ in diameter) for MHD plasma duct. Outside diameter and depth of the liquid helium vessel were $150 \mathrm{~cm}$ and $330 \mathrm{~cm}$, respectively.

As a result of the test running the following characteristics of the magnet and cryostat were assured.

Central field
Field uniformity
Current decay time-constant
(persistent mode)
Boil-off rate of liquid helium
(with magnet not energized)

1. 緒言

本報告は昭和 42,43 年度にわたって通産省大型プ ロジェクトの一環として日立製作所が研究を委託され た「 $45 \mathrm{kG}$ 超電導電磁石の試作研究」に関するもので

$\begin{array}{cc}\text { Test Results } & \text { Design Values } \\ 47 \mathrm{kG} & 45 \mathrm{kG} \\ 95 \% & >85 \% \\ >1,300 \text { hours } & >720 \text { hours }\end{array}$

$101 / \mathrm{h}$

$111 / \mathrm{h}$

ある。

日立製作所では昭和 37 年頃から超電導材料の研究 を開始し, $\mathrm{Nb}-\mathrm{Zr}-\mathrm{Ti} 3$ 元合金 ${ }^{11}$ 線を開発し, 次いで その応用として超電導マグネットの研究を行なってい た。本委託研究はこれらの研究成果を基礎として出発

Vol. 5 No. 2 (1970) 
し，42年度には設計および装置の製作を行ない社内で の予備試験を行なった。43年度にはこれらの装置を電 気試験所田無分室に運搬, 据付.配線等を行なった後, 総合運転試験によって性能を確認した。

なお総合運転試験は同じく委託研究によって製作さ れた三菱電機製へリウム液化冷凍機系と組み合わせて 行なわ机た。

\section{2. 超電導電磁石}

\section{1 線材（超電導ストリップ）}

超電導ストリップの設計は次の方針に従って行なっ た。

（i ）中心磁束密度が. $45 \mathrm{kG}$ の超電導マグネットの 線材の経験する最大磁束密度は, $50 \sim 55 \mathrm{kG}$ 程度であ ると想定し, この条件下でも $500 \mathrm{~A}$ 以上の通電容量を 持ちしかも十分に安定化さ机ていること。

(ii） $45 \mathrm{kG}$ の超電導マグネットのコイル形状は， 常温空間の直径に対する仕様が $25 \mathrm{~cm}$ であることか らクライオスタットの断熱層の厚さを考慮して内径 38 $\mathrm{cm}$ の鞍形とした。

(iii）超電導ストリップは端面冷却としたため絶縁 テープは片平面貼付とした。絶縁テープはコイルに成 形した時, あるいは液体へリウムに浸漬した時はがれ ないだけ十分の接着強度を有すること。

（iv）長尺の超電尊ストリップの製作が可能である こと。

以上の点を種々検討した結果, 日立で開発した直径 $0.25 \mathrm{~mm}$ の $\mathrm{Nb}-40 \mathrm{Zr}-10 \mathrm{Ti}$ 合金線を 10 本, 平角 銅に平行に埋め込んだ HISUPER-10X ストリップを 設計した。10本の素線の埋为込みに際してはコイル成 形時に線材㐰加わる各種加工を考慮して 2 段 5 列に埋 め込む方式を採用することとし，ストリップ断面を 7.0 $\mathrm{mm}^{\mathrm{w}} \times 1.6 \mathrm{~mm}^{\mathrm{t}}$ と決定した。

Fig. 1 は HISUPER-10X スト リップの設計断面である。また Fig. 2 にストリップの $\mathrm{H}-\mathrm{I}_{\mathrm{c}}$ 規格值を示 した。

\section{2 コイルの設計}

2.1 で述べた安定化線材を使って $45 \mathrm{kG}$ 鞍形超電導コイルを設計する に当って,下記の基本方針を定めた。

(i ) 超電導コイルは完全安定化 領域で運転できることを目標に設計 する。
本コイルは $5 \mathrm{MJ}$ 程度の貯蔵エネルギーを持つ大型 超電導マグネットであり, 定格運転では絶対に常電導 転移 (quench) することがない設計にすることが必要 である。コイルの安定化パラメータ $\alpha_{c}$ は Stekly ${ }^{2)}$, その他に従い次式で与えられるものとした。

$$
\alpha_{c}=\frac{\rho_{d} I_{d}{ }^{2}}{\beta q_{d} P_{c} A}
$$

ここに $\rho_{d}=$ 銅の設計比抵抗, $I_{d}=$ 設計コイル電流, $\beta=$ 露出係数, $q_{d}$ 設計熱流束, $P_{c}=$ ストリップの冷 却面周囲長， $A$ 二銅断面積である。

コイル層間のスペーサ間隔と臨界熱流束 $q_{c}$ との関 係は予測定したクーリング・チャネルのモデル実験 の結果 ${ }^{3)}$ を参考にした。モデル実験ではチャネル壁の 片面にヒーターを置き，この面のみ全面発熱した場合 の液体へリウム中での核沸騰から膜沸騰に転移する臨 界熱流束とチャネルの間隔, 傾き角との関係を測定し ておいた。コイル全体の設計熱流束 $\left(\beta q_{d}\right)$ はこれらの 值から $0.3 \mathrm{~W} / \mathrm{cm}^{2}$ とした。

Fig. 2 に示すコイル設計銅安定曲線 $\left(\infty_{c}=1\right)$ と次 に述べる磁界分布計算の結果から決まるコイル負荷曲 線との交点として第I，第IIブロックの各設計電流を 求めた（第 I，第IIブロックについては次に述べる)。

(ii) コイル全体を第 I ブロック（内層側）と第II ブロック（外層側）に分割し，その励磁電流を外層側 を大きく内層側を小さくする分割励磁方式とする。こ のために Fig. 3 に示すように 1 台の直流電源と制御 抵抗を組み合わせた分割励磁方式を考案した。

コイルの最終設計值を Table 1 亿示す。

\section{3 電磁力および磁界分布の計算}

鞍形コイル各部に㗢く電磁力掞よび磁界分布の計算 は日立 HITAC-5020F を使って行なった。計算化当 ってはコイルは Fig. 4 に示すように計算に便利な形 にモデル化し，端部の半円形電流と直線部の直線電流

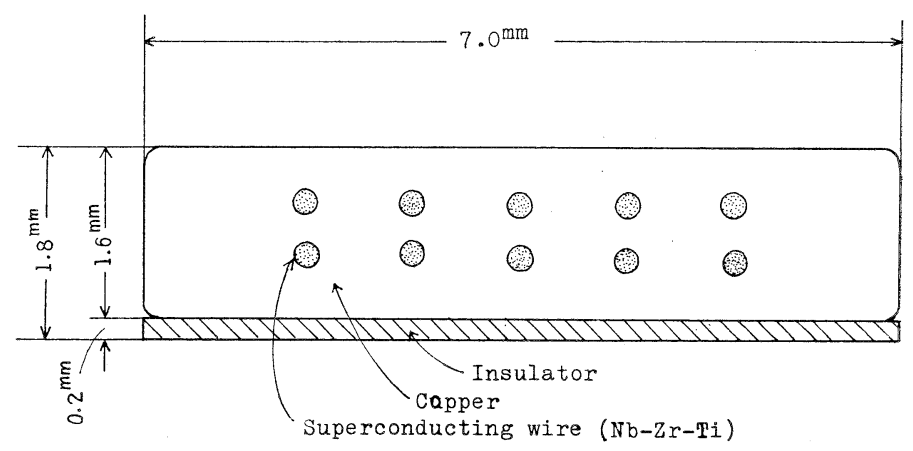

Fig. 1 Cross-section of HISUPER-10X strip. 


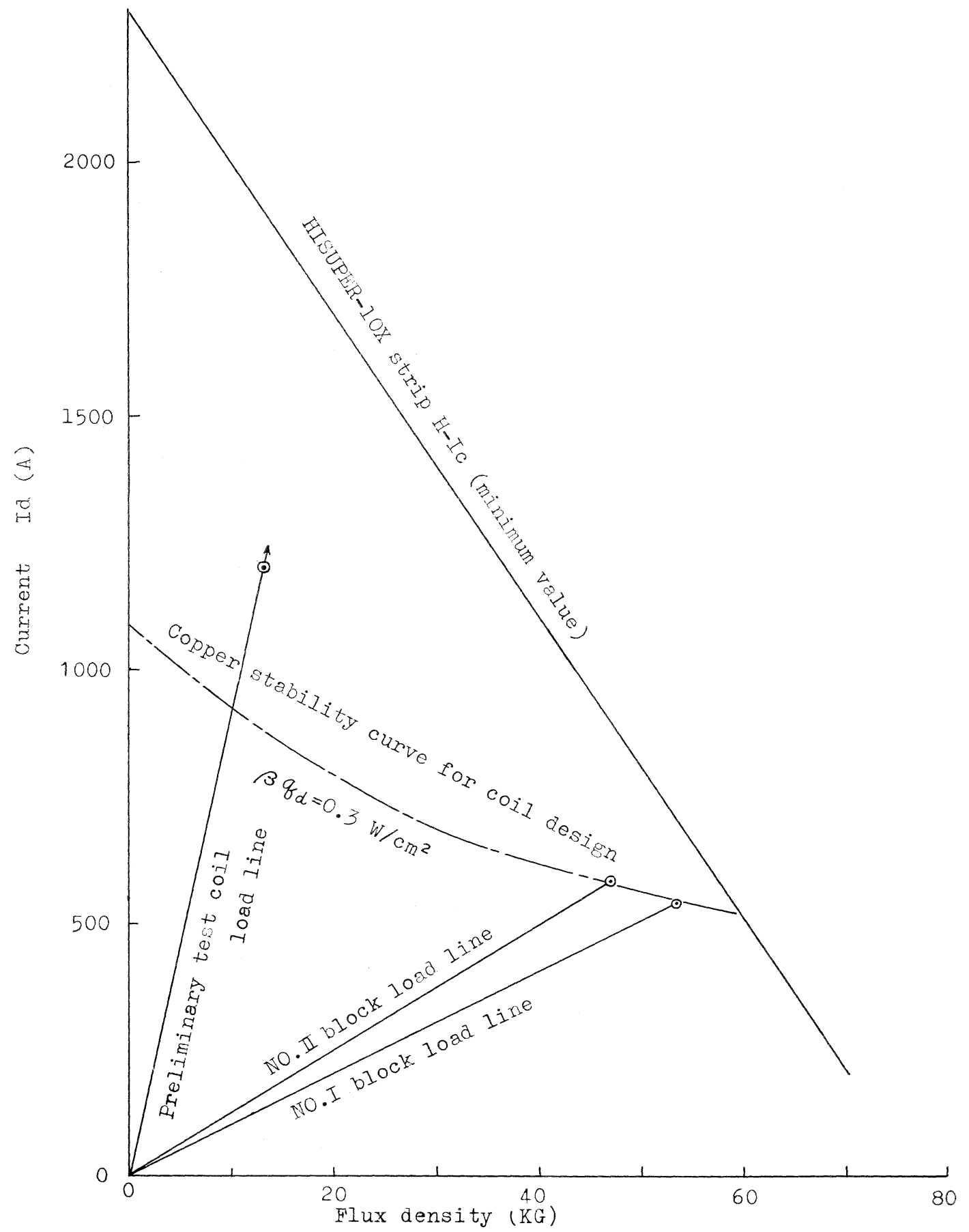

Fig. 2 Copper stability curve and coil load line. 


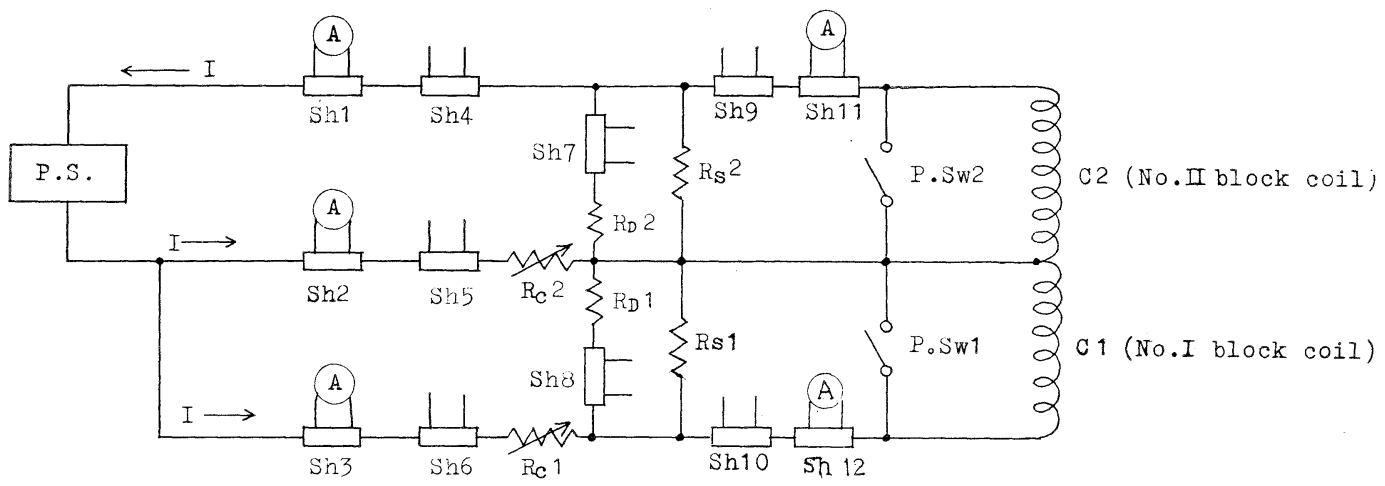

\begin{tabular}{|c|c|c|c|}
\hline P.S. & $\begin{array}{l}\text { D.C. } 2000 \mathrm{~A}-20 \mathrm{~V} \\
\text { Stabilized Power Supply }\end{array}$ & $R_{D}$ & Shunt Protection Resistor \\
\hline A & Ammeter & Rs & Shunt Stabilizing Resistor \\
\hline $\begin{array}{l}\text { Sh } 1 \sim 3 \\
\text { Sh } 11.12\end{array}$ & Shunt resistor for ammeter & Rc & Controlling Resistor \\
\hline $\operatorname{Sh} 4 \sim 10$ & for recorder & $\mathrm{C}$ & Superconducting Coil \\
\hline P.Sw & Persistent Switch & & \\
\hline
\end{tabular}

Fig. 3 Coil energizing circuit.

Table $145 \mathrm{kG}$ saddle shaped coil specifications

\begin{tabular}{|lc|}
\hline Central magnetic field $\mathrm{B}_{0}$ & $45 \mathrm{kG}$ \\
Effective volume for MHD power generation & $10 \mathrm{~cm} \phi \times 60 \mathrm{cmL}$ \\
Coil inside diameter & $38 \mathrm{~cm} \phi$ \\
Coil outside diameter & $88 \mathrm{~cm} \phi$ \\
Coil length & $180 \mathrm{~cm}$ \\
No. of total turns & 7,630 \\
No. of layers & 22 \\
\hline
\end{tabular}

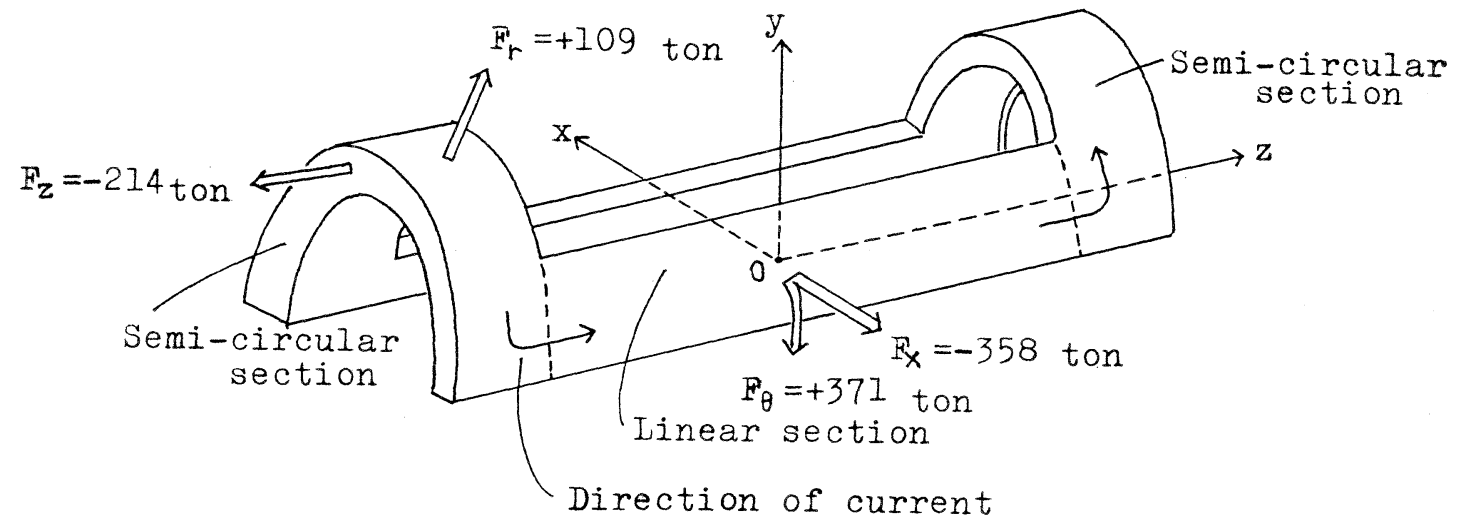

Saddle shaped coil

Fig. 4 Electro-magnetic body force. 


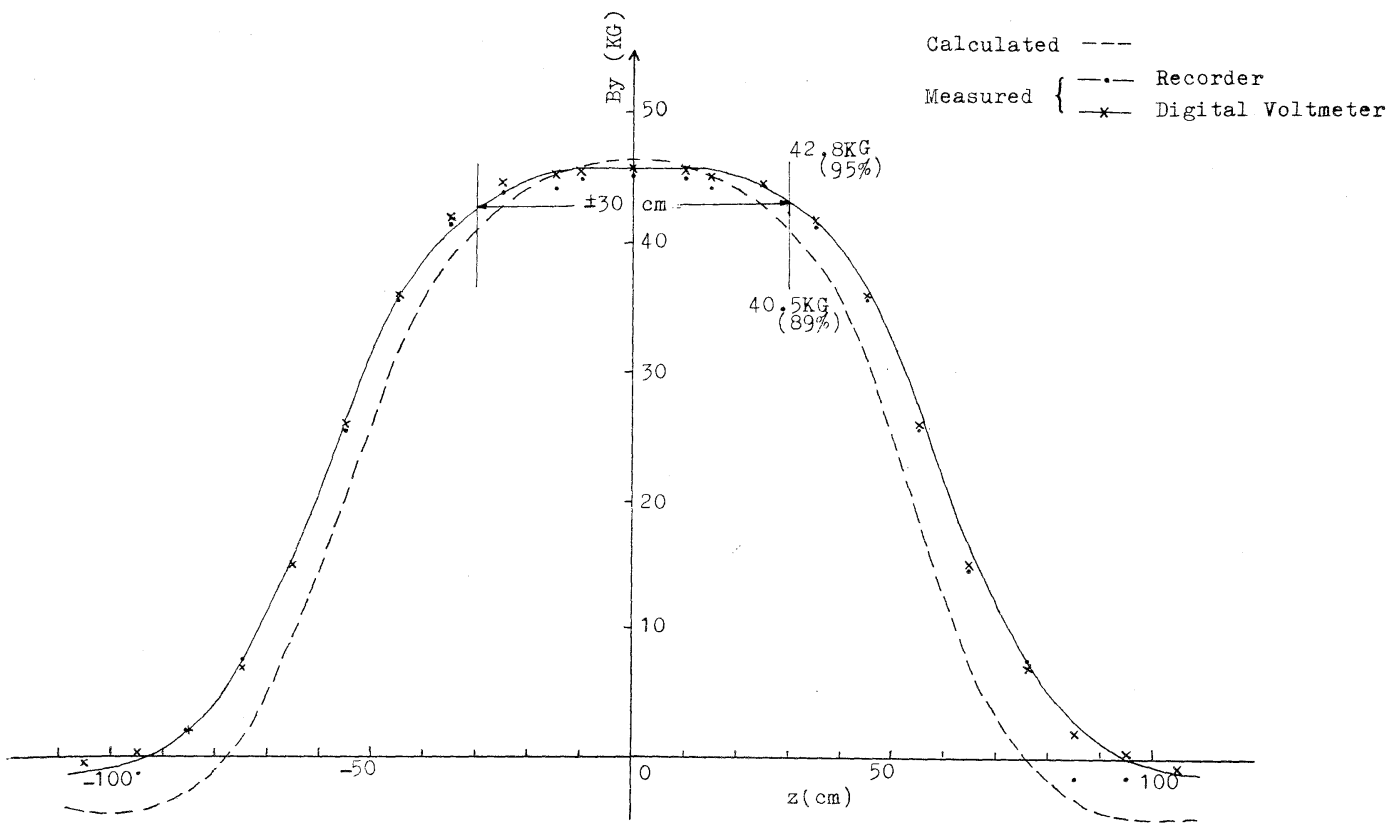

Fig. 5 Magnetic neld distribution on $Z$ axis; By $(z)$.

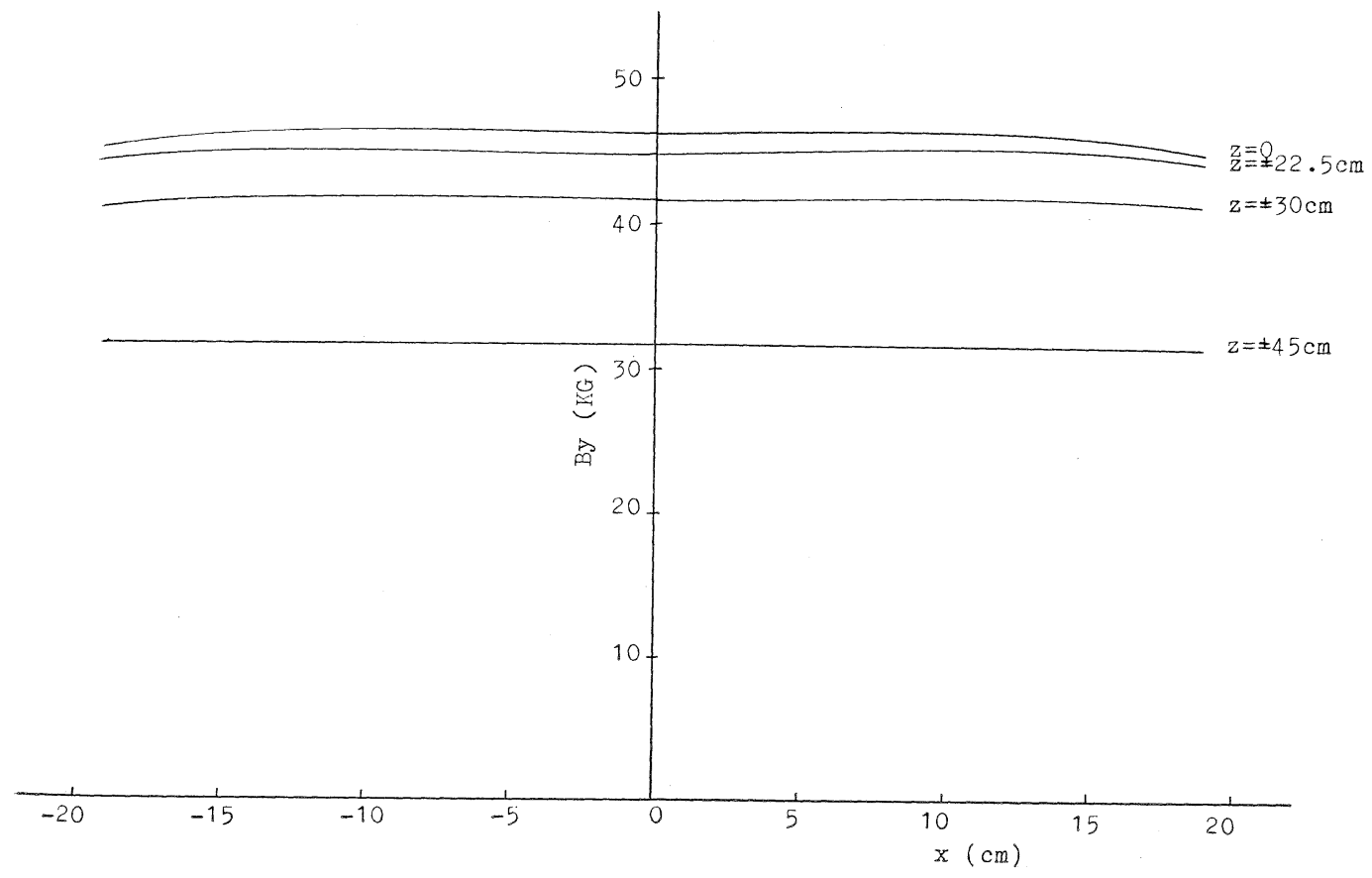

Fig. 6 Magnetic field distribution; $\mathrm{By}(\mathrm{x})$ $y=0, z=0, \pm 22.5, \pm 30, \pm 45 \mathrm{~cm}$. 
による力と磁界を計算した。

計算の結果として導体各部に作用する体積力 (body force) を同図に示してある。直線部には $F_{x}$ として 外向きに -358 ton, $\mathrm{F}_{\theta}$ として +371 ton の力が, また端部には $\mathrm{F}_{z}$ として外向きに -214 ton, Fr とし てふくらもらとする方向に 109 ton の力がそれぞれ働 く。図では片側コイルだけを考えているが完全なコイ ルでは $\mathrm{F}_{x}$ は2 倍しなければならない。またコイル層 間，ターン間の圧縮力についても計算を行なった。コ イル設計にはこれらの力に対し十分耐え得る支持構造 を考えなければならない。

常温空間中心軸上の磁界分布を Fig. 5 に点線で示 す。また常温空間内磁界分布として $z$ をパラメータに $y=0$ での $x$ 方向分布を Fig. 6 に， $x=0$ での $y$ 方向 分布を Fig. 7 に示した。Fig. 5〜7 から分かるよう に $z= \pm 30 \mathrm{~cm}, x=y= \pm 19 \mathrm{~cm}$ で考えられる空間内 の $\mathrm{B}_{y}$ に関する均一度の計算值は約 $89 \%$ である。

またコイル各部の磁界分布を計算した結果，第 I， 第II各ブロックの超電導線材が経験する最大磁束密度 はそれぞれ $53.5 \mathrm{kG} ， 47 \mathrm{kG}$ であった。Fig. 2 にコ イル負荷曲線を示した。

\section{4 永久電流スイッチ}

永久電流励磁実験を行ならための永久電流スイッチ はクライオスタットの外部から機械的に開閉ができる 機構にした。市なわらクライオスタット上蓋上に水平 に取り付けられたシャフト終端の円形ハンドルを回転 することによってスイッチを開閉する。永久電流スイ ッチ主要部の構造を Fig. 8 に示す。スイッチ接片は 厚さ $1 \mathrm{~cm}$, 有効接触面積 $18.5 \mathrm{~cm}^{2}$ の無酸素銅 $(\mathrm{OFC})$ で接触面には厚さ $250 \mu$ のインジウムコーティングを 施した。

Fig. 9 にクライオスタットに組み込み中の超電導 電磁石を示す。

\section{3. クライオスタット}

\section{1 クライオスタットの設計}

超電導電磁石を収納するクライオスタットは，中心 部に $25 \mathrm{~cm} \phi$ の常温空間を有する縦形同心円筒状とし た。

液体へリウム貯槽と外側容器との間は熱絶縁のため に高真空に保持し，液体窒素による泠却と蒸発へリウ ムガスの顕熱による冷却圭併用した。液体へリウム貯 槽と外側容器との間には, 液体窒素を流通させるため の蛇管を巻回した輻射しゃへい用の銅板を挿入し，外

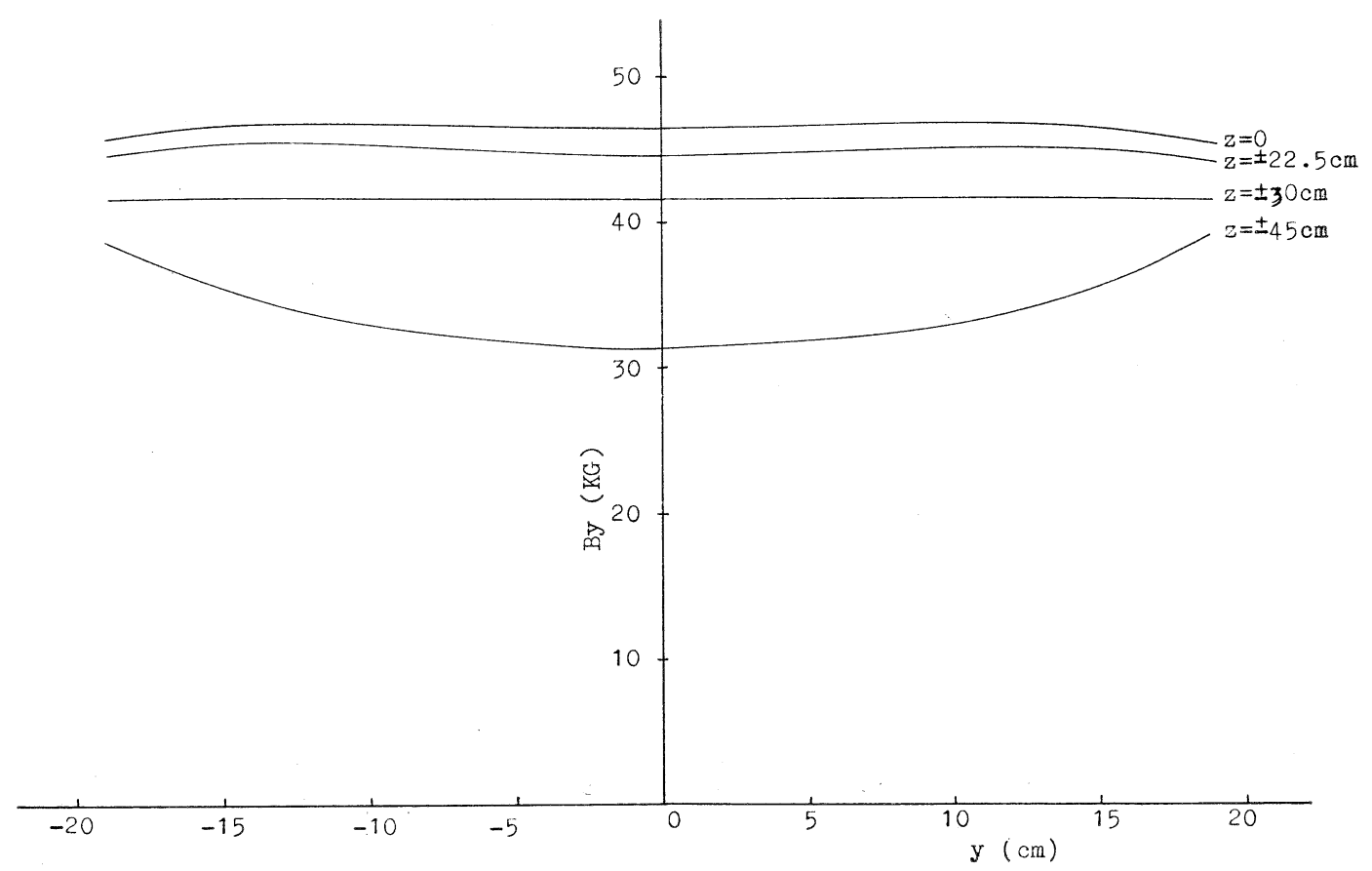

Fig. 7 Magnetic field distribution; By (y) $\mathrm{x}=0, \mathrm{z}=0, \pm 22.5, \pm 30, \pm 45 \mathrm{~cm}$. 
a) Contacting plate

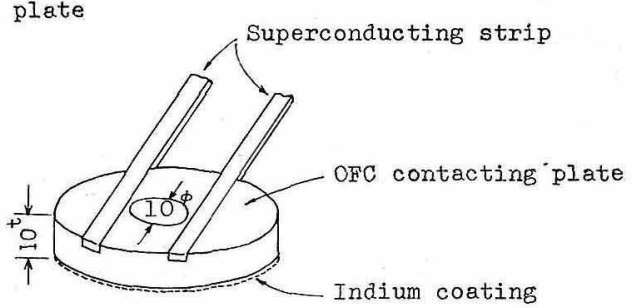

b) Persistent switch assembly

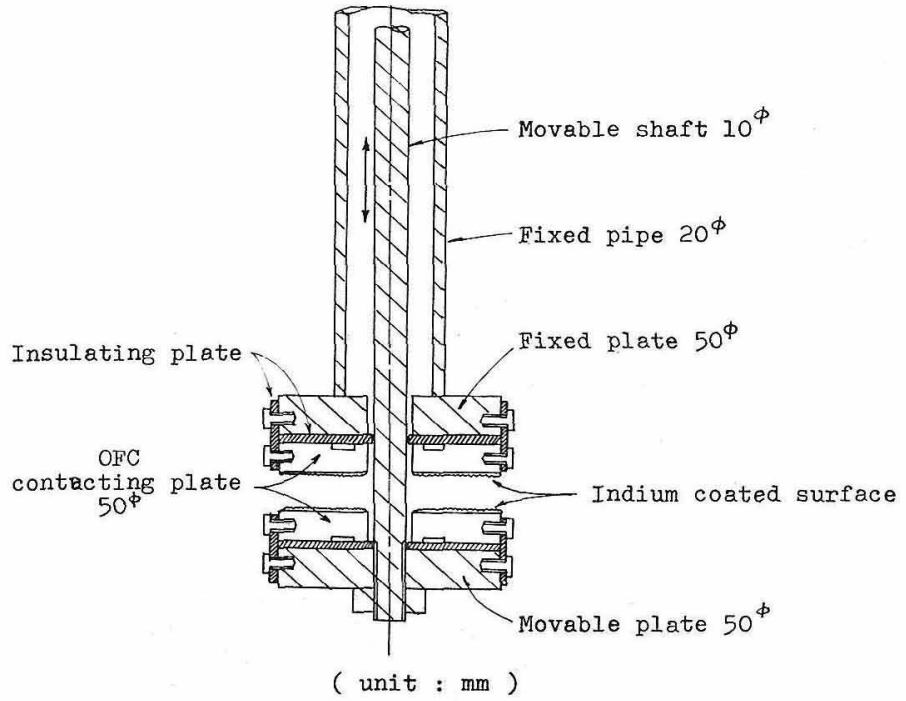

Fig. 8 Mechanical persistent switch.

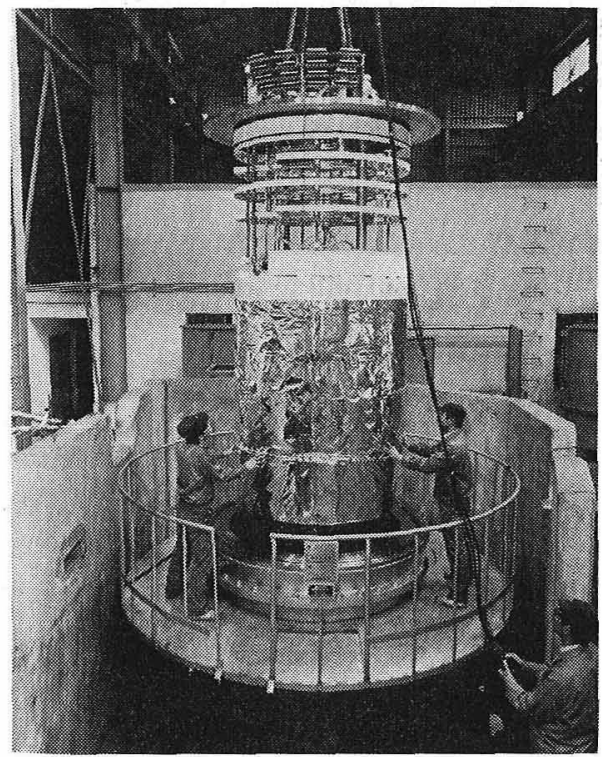

Fig. 9 Superconducting magnet assembly.
筒部および底部には輻射しゃへい板 の熱絶縁のために積層断熱材を巻く 方式とした。液体へリウム貯槽の上 部には常温フランジ面からの侵入熱 を防ぐために，4層の発泡スチロー ルと金属板とからなる上部輻射しゃ へ、板と液体窒素で泠却された輻射 しゃへい板を插入した。したがって， 液体へリウムの周囲はほぼ完全に液 体窒素で包网していることになる。 さらに液体へリウム貯槽の壁は伝導 による侵入熱低減のためその厚さは できるだけ薄くし，材質は低熱伝導 性のステンレス鋼とした。またこ の貯榑壁は上部輻射しゃへ々板や測 定用導線など各種挿入物とともに蒸 発へリウムガスで泠却する。

本クライオスタットは特に MHD 発電機と組み合わせて使用すること を目的とするものであり，発電ダク 卜を通過した後のプラズマ流路があ まり長くならないためにも，超電導 コイル上部と上蓋の閒の距離をでき るだけ縮める設計方針を採り，しか も液体へリウムの熱侵入を極力少な くするように留意した。したがって， コイル長約 $2 \mathrm{~m}$ に対してクライオスタットの哚さは $3.3 \mathrm{~m}$ であり, 従来のこの種のクライオスタットに比 ぶてずっと浅い設計になっている。しかも後述するよ うに, 液体へリウム蒸発量も非常に少ない設計とする ことができた。

また, 安全性の面からクライオスタットとその周辺 機器は, すぶて人間が近奇らなくても運転が可能なよ うにクライオスタット操作盤で制御できるように考慮 した。

クライオスタットの主要寸法を Table 2 に, また

Table 2 Cryostat specinfcations

$\begin{array}{lr}\text { Room temperature space diameter } & 25 \mathrm{~cm} \phi \\ \text { Liquid He vessel inside diameter } & 32 \mathrm{~cm} \phi \\ \text { Liquid He vessel outside diameter } & 150 \mathrm{~cm} \phi \\ \text { Liquid He vessel depth } & 330 \mathrm{~cm} \\ \text { Cryostat outside diameter } & 180 \mathrm{~cm} \\ \text { Cryostat height } & 450 \mathrm{~cm}\end{array}$




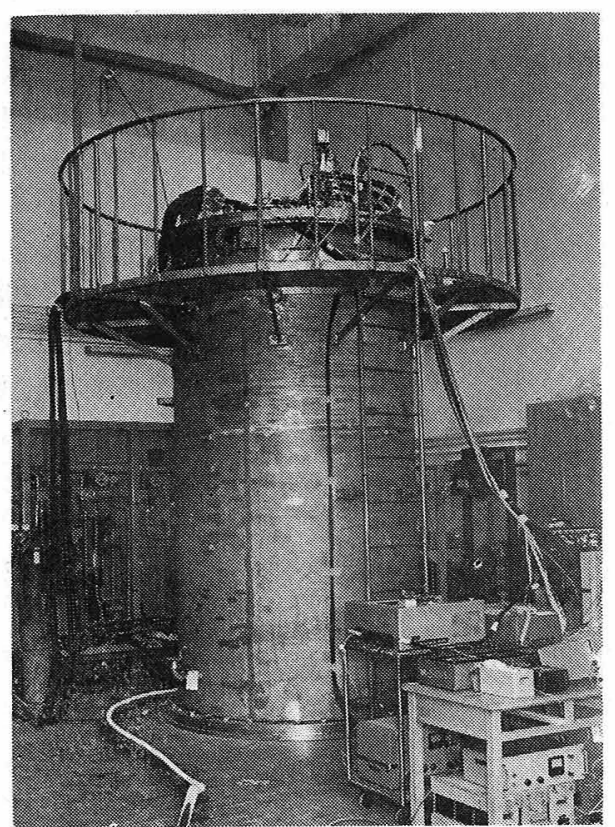

Fig. 10 Cryostat.

外観写真を Fig. 10 に示す。

\section{2 熱計算}

クライオスタットの熱計算は, 輻射, 伝導による侵 入熱, パワーリードとコイル接続部でのジュール発熱 につけて詳細に行なった。その結果は, 輻射による侵 大熱 $3.9 \mathrm{~W}$, クライオスタット壁からの伝導による侵 入熱 $1.5 \mathrm{~W}$, 測定用導線, その他の伝導による侵入熱 $1.0 \mathrm{~W}$ ，パワーリードの伝導による侵入熱 (ジュール 発熱を含む侵入熱) $0.7 \mathrm{~W}$ (通電中 $4.0 \mathrm{~W}$ ) である。

\section{3 安全対策}

本超電導コイルの運転時の 貯蔵エネルギーは約 5 MJ に達する。このエネルギーがコイルの常電導転移 その他の原因によって瞬時に液体へリウムを気化する ようなことがあれば爆発事故を起こすおそれがある。 これに対しては，下記の対策を用意して十分安全な設 計とした。

（i）超電導線材は安定化されたものを用い，コイ ル設計に当っても定格運転時には完全安定化領城にあ る設計方針を採った（前述）。

(ii) 万一，常電導転移が起こった場合はこれを検 出し, 励磁電源の掃引停止さらには安全回路働作によ って貯蔵エネルギーの大部分を外部保護抵抗に消費さ せ, 液体へリウムの気化を最小限に止めるための安全 回路を設けた。 (iii) クライオスタット内部で液体へリウムの蒸発 が激しくなり内圧が上昇した場合は，次の順序に従っ てそれぞれの圧力で安全弁が働作し，へリウムガスを 排出して内圧の上昇を防ぐ設計とした。

(1)バイパス弁 $\left(0.4 \mathrm{~kg} / \mathrm{cm}^{2} \mathrm{G}\right)$, (2)大気開放弁 $(0.5$ $\left.\mathrm{kg} / \mathrm{cm}^{2} \mathrm{G}\right)$, (3) バネ安全弁 $\left(0.6 \mathrm{~kg} / \mathrm{cm}^{2} \mathrm{G}\right)$, (4)破壊板 $\left.0.8 \mathrm{~kg} / \mathrm{cm}^{2} \mathrm{G}\right)$ 。これらはクライオスタットの上部あ るいは配管に取り付けた。

(iv）クライオスタットの三方をコンクリート壁で 囲い, 万一爆発事故が起こっても運転要員その他人身 の安全をはかった。

上記の他, 地震, 火災, 停電その他の事故詨策にも 万全を期した。

\section{4. 付属装置}

\section{1 計測装置}

超電導磁石の予冷, 液体へリウムの注入, 励磁実験 を通じて計測, 測定を行ならため下記の各種測定素子 および測定器を準備した。これらの測定はすべて遠隔 操作により計測制御盤(Fig. 11) で行なえるようにし た。

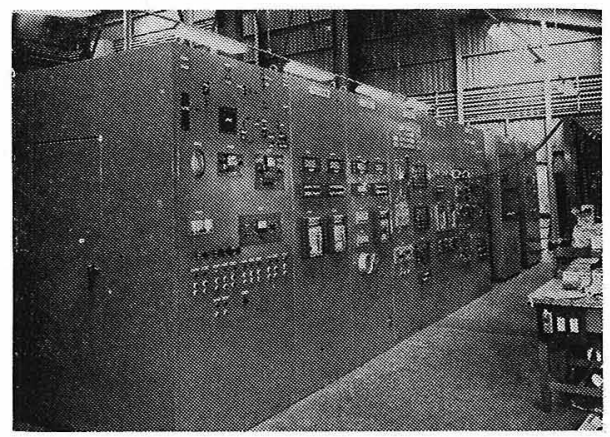

Fig. 11 Controlling and measuring panels.

(a) 端子電圧測定

励磁実験中の常電導部の発生その他の異状現象を観 測するため，コイル各ユニットの端子電圧測定用の端 子を用意した。実験に当ってはコイル全体の端子電圧 と各ブロック最内層コイルの端子電圧を 6 ペンレコー ダに記録するようにした。これ以外の端子電圧はビジ コーダに記録させた。

(b) 電流測定

Fig. 3 に示したように, 励磁回路中の各部分の電流 が測定できるよらにシャント抵抗を Sh 1〜Sh 12 ま

低温工学 
で 12 個設けた。このうち Sh 1〜3 および $11 ， 12$ は 直接電流計に接続し, Sh 4〜10を6ペンレコーダに 入れて記録できるようにした。

(c) 磁界測定

磁界測定はコイル線材が経験する磁界と常温空間内 の磁界の 2 種類について行なった。前者はコイル各部 の計測しようとする位置に磁界の向きにホール素子を 設置し, 後者は常温空間内を自由にスライドできる治 具にホール素子を設置した。電磁石励磁中にこの治具 を常温空間中心軸に沿って移動させ, 中心軸上磁界分 布を測定できるようにした。ホール素子はシーメンス 社製 SBV-552 使用し, 前者は液体へリウム中 4.2 。 K で，後者は室温でそれぞれ較正した。

実際の測定にあたっては常温空間内の温度変化が問 題になるが，加温した窒素ガスを常時流し較正時の温 度に近くなるように保った。また, ホール素子を較正 する際には, 常温とドライアイス温度の二通りについ て出力電圧の温度依存性を調心゙たが, その差は $45 \mathrm{kG}$ 付近で $1 \% / 95^{\circ} \mathrm{C}$ 程度でほとんど差がないことを確か めておいた。ホール素子の制御電流は定電流電源によ り $10 \mathrm{~mA}$ 流した。

(d) 温度測定

主として予冷時の温度測定用に, 銅コンスタンタン 熱電対をクライオスタット拉よびコイル各部に取り付 けた。また運転中のコイル温度上昇測定用には銅一金 合金熱電対を, 液体へリウム沸騰検出用にカーボン抵 抗を取り付けた。

(e) 圧力測定

クライオスタットの内圧測定のために，ブルドン管 式連成計とストレングージを使った絶対圧伝送器によ って指示，記録することにした。

(f) 流量測定

流量の制御と直続のために浮式流量計を，また全流 量はベンチュリ管によって検知し, 記録のために変換 器としてストレンゲージを使った差圧伝送器を使用し た。

( $\mathrm{g}$ ) 液面計測

ヘリウムの液面測定にはさまざまな方法があるが， どれも一長一短があり特に優れているものがない。通 常は播動式カーボン抵抗の抵抗測定で比較的容易にか つ高い精度で液面測定が可能であるが, 本装置はクラ イオスタット周辺への人間の接近なしに測定する必要 があるので, 次に述心゙る固定式のカーボン抵抗を使用 した。

Vol. 5 No. 2 (1970)
クライオスタットの底から $20 \sim 200 \mathrm{~cm} の$ 範囲に, $20 \mathrm{~cm}$ 毎に置かれた 10 個のカーボン抵抗に若干の電 流を流して熱を発生させておくと, 液中と気中の熱伝 達の差から温度上昇の違いが現われ, 液体へリウムの 液面を知ることができる。この差が最も大きくなるの は, カーボン抵抗表面の液中における熱伝達が核沸騰 から膜沸騰に移行する直前であるが, 熱損失も大きい ので最適值より低目の電流を選んだ。Allen-Bradley 社製 $1 / 10 \mathrm{~W}, 100 \Omega$ モールド抵抗の最適值は $20 \mathrm{~mA}$ 付近であるが，本計測装置には $2.5 \mathrm{~mA}$ を選んだ。

また，連続的に液面を記録監視するためにハンプソ ン式の差圧計で液面を測定した。しかし $4.2 \circ \mathrm{K}$ の気 体でも液体の $13 \%$ の密度を有するから, 差圧から液 量を求める場合この誤差は無視できない。液体の貯蔵 量を知る目安としては使用できるが, 高精度の液面読 みとりには不適当である。

(h) 歪 測 定

電磁石励磁中の各種応力測定にはこの目的のために 開発した強磁界, 極低温用接着型歪測定法を用いるこ とにした。

ゲージ素子として, 新興通信工業製 S 108 D ワイ ヤゲージ4)を使用した。本素子は $1.2 \circ \mathrm{K}$ での磁気抵 抗効果のため見掛け歪を生じるが，見掛け歪の磁界依 存性が Kohler の法則に従い，0２0 kOe の低磁界側 で放物型で $20 \mathrm{kOe}$ 以上の高磁界側で直線性を示す。 さらに常温から $4.2 \circ \mathrm{K}$ の極低温までの温度範囲にわ たってゲージ率の温度依存性は極めて小さく( $\pm 0.5 \%$ 最大)，0〜70 kOe の強磁界によってもゲージ率はほ とんど変化しない。また各ロット内あるいは各ロット 間で高磁界側でも見掛け歪およびゲージ率のバラツキ は極めて少ない。

本ゲージを超電導コイル電磁力サポート表面その他 に貼付し，動歪計および 6 ペン記録計によって記録測 定した。なお本装置の貼付個所近傍にホール素子を設 置して磁界を測定した結果, 貼付位置における磁界の 影響は極めて小さかつた。

\section{2 液体窒素タンク}

クライオスタットの輻射しゃへい板の泠却および排 気装置のトラップ冷却用液体窒素供給のために, Fig. 12 に示す液体窒素タンクを製作した。クライオスタ ットの液体窒素使用量は定常時約 $30 l / \mathrm{h}$ であり, 200 時間分の液体窒素を貯蔵することを目標に張込み容積 は $6,000 l$ とした。 


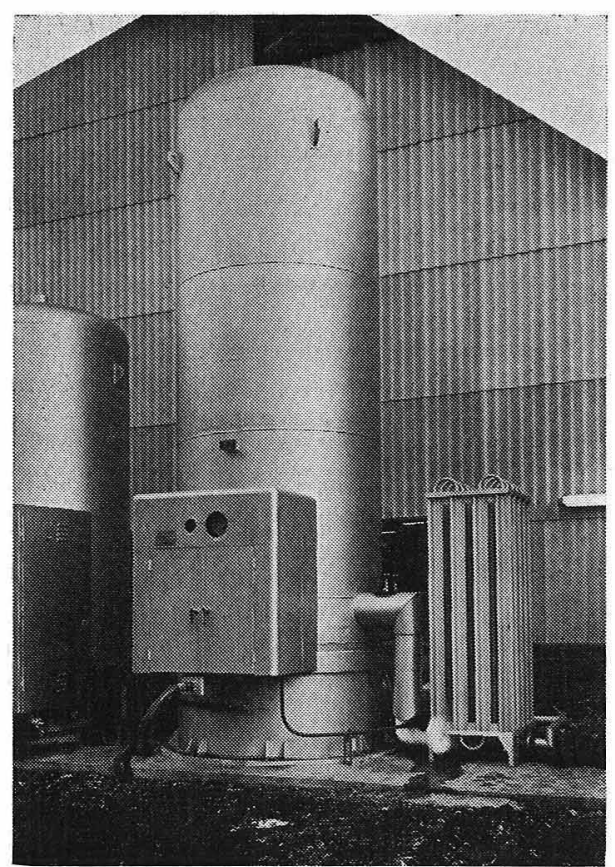

Fig. 12 Liquid nitrogen tank.

\section{5. 運転試験}

\section{1 予備運転試験結果とその検討}

予備運転試験は総合運転試験に先立って，製作した 各機器の性能を確認し各種測定法を検討するために社 内で行なった。しかし $45 \mathrm{kG}$ 鞍形コイル全体を液化泠 凍装置なしで $4.2^{\circ} \mathrm{K}$ まで泠却することは莫大な量の 液体へリウムを必要とするために不可能である。した がって, 鞍形コイルは最内層 1 セグメント ( 2 層捲 き) のみを組み込み，クライオスタットにできる空隙 には液体へリウム排除用のダミー容器を別に製作して 取り付けた。クライオスタットやその制御盤その他付 属装置，液体空素タンクは本番のものをそのまま使用 した。

予備試験の実験項目は次の通りである。a，液体窒 素による初期冷却と液体へリウムの注入， b. コイル 励磁特性測定, c. 中心磁束密度, 線材経験磁束密度 測定, d. 永久電流励磁特性測定, e. 急速励滋と1 ンダクタンス測定，f. クライオスタット性能測定, g. 眝蔵エネルギー除去実験, h. 励磁時の鞍形コイ 几の歪測定。実験は液体へリウム約 4, $000 l$ を米国 A IRCO 社から空路輸入して行なった。

実験結果については紙数の関倷加ら簡単に触れるに 止める。実験 bに掠いてコイル電流 $1,200 \mathrm{~A}$ まで励磁
したが，常電導転移その他の異常現象は全く現われな かった。電磁力サポートの強度は $1,200 \mathrm{~A}$ までで設計 したのでこれ以上の励磁は行なわなかった。さらに実 験 $\mathrm{e}$ では 1 分 12 秒で $1,200 \mathrm{~A}$ に達する急速励磁を行な

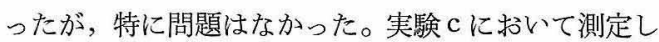
た $900 \mathrm{~A}$ 通電時の中心磁束密度は $6.9 \mathrm{kG}$, 線材経験 磁束密度は $10.0 \mathrm{kG}$ であった。HISUPER-10X スト リップの $\mathrm{H}-\mathrm{I}_{\mathrm{e}}$ 特性とこの測定值によるコイル負荷曲 線を Fig. 2 に示した。前述のごとく, $45 \mathrm{kG}$ 鞍形コ イルに対する銅安定曲線は 臨界熱磁束 $=0.3 \mathrm{~W} / \mathrm{cm}^{2}$ で設計されているが，コイル電流 $1,200 \mathrm{~A}$ はこれを大 幅に上备る電流值をで励磁しても問題なかったことを 意味し，本番コイルで $45 \mathrm{kG}$ を発生し得る見通しは 明るくなった。

電磁力サポートの歪測定結果の一例を Fig. 13 亿示 した。各歪ゲージの出力はコイル電流の 2 乗に比例し て変化していることが分かる。コイル電流 $1,200 \mathrm{~A} の$ 時位置 $\mathrm{S}_{1}$ に打ける歪の最大值は $+4.7 \times 10^{-4}$ であり， ステンレス鋼のヤング率を $2.03 \times 10^{6} \mathrm{~kg} / \mathrm{cm}^{2}$ とすれ ば応力は $9.5 \times 10^{2} \mathrm{~kg} / \mathrm{cm}^{2}$ となる。

\section{2 総合運転試験結果とその検討}

総合運転実験は下記の項目を主目的として行なっ た。

（i）鞍形超電導コイルの中心磁束密度 $B_{0}=45 \mathrm{kG}$ の達成。

(ii) クライオスタット常温空間中の MHD 発電ダ クト有効体積 $(10 \mathrm{~cm} \phi \times 60 \mathrm{~cm}$ 長) 内の磁束密度均一 度が $B_{0}$ の $85 \%$ 以上であることの確認。

（iii）永久電流励磁を行なった場合，減衰時定数が 720 時間以上であることの確認。

(iv) クライオスタット特性の確認。特に非通電時, 通電時, 永久電流励磁時の液体へリウム蒸発量が目標 值以内であることの確認。

（v） 励磁回路，クライオスタッ卜操作盤，計測装 置, 液体窒素タンクなどの諸系統が正常に働作するこ との確認。

これらの目的を達成するために次の実験項目を行な うことにした。A．クライオスタットの性能測定, B . 準備励磁, C. 低速励磁と磁束密度分布の測定, D. 中速励磁, E. 永久電流励磁。

実験は電気試験所田無分室超電導マグネット建屋内 で行なった。装置の全景（三菱電機製液化冷凍系を含 む)を Fig. 14 に示す。

(a) コイルの予冷 


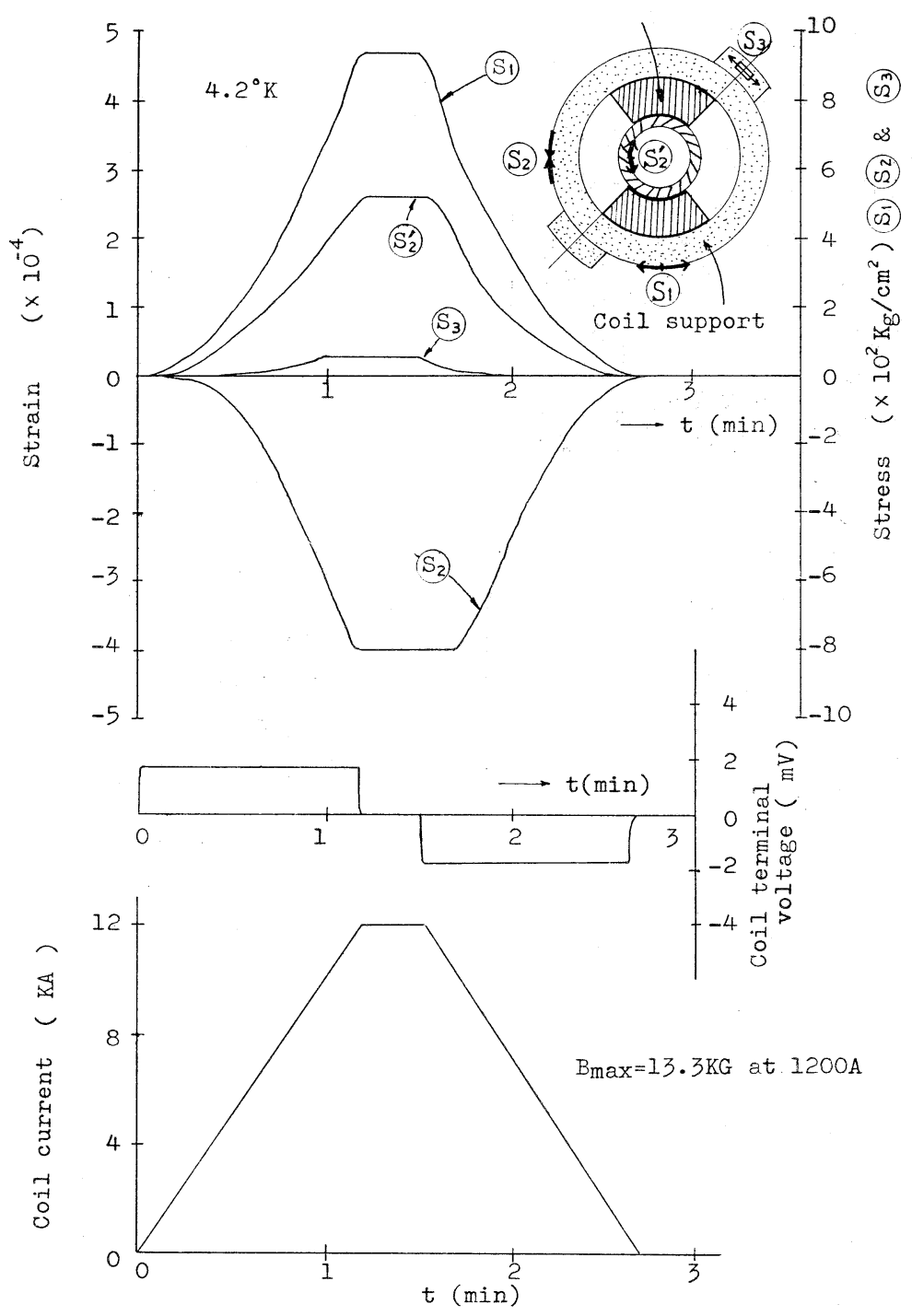

Fig. 13 Strain and stress of saddle shaped coil (Preliminary test running).

コイルの予冷は三菱電機製の冷凍機によって行なわ れたが，その時のコイル温度はFig. 15 に示すような 変化を示した。戝には代表的な点の温度だけプロット したが，同一高さではほぼ同一温度変化を示した。30 ${ }^{\circ} \mathrm{K}$ 以上は熱電対で， $30^{\circ} \mathrm{K}$ 以下はカーボン抵抗温度 計 (図中 $\mathrm{T}_{5}$ ) でコイル温度を測定したが，40〜20K 間は両者とも精度が悪い。コイルの最終到達温度は 14 ○Kであった。

第 3 次予冷（液体へリウムによる予冷）はきわめて スムースで, 所要液体ヘリウム量は $50 l$ 程度と推定さ れる。しかしその後の液体へリウムの張込みにはかな

Vol 5 No. $2(1970)$
りの時間を要した。その模様を Fig. 16 亿示す。

（b）超電導コイル特性（実験項目 C，D）

実験 $\mathrm{C}$ 低速励磁では $5.6 \mathrm{~A}$ / 分 の比較的遅い掃引速 度で励磁した。初めての励磁なので 200〜100A おき に一時掃引を停止して, 端子電圧, 液体へリウム蒸発 量，その他異状現象が現われていないことを確認しな がら慎重に励磁電流を増加して行った。励磁開始後約 4 時間で第 I ブロックコイル電流 $480 \mathrm{~A}$ ， 第II ブロッ クコイル電流 $525 \mathrm{~A}$ で中心磁束密度 $B_{0}=45 \mathrm{kG}$ に達 した。後述の磁束密度分布測定を行なった後, さらに 励磁電流を第 I ブロック $500 \mathrm{~A}$, 第 II ブロック $550 \mathrm{~A}$ 


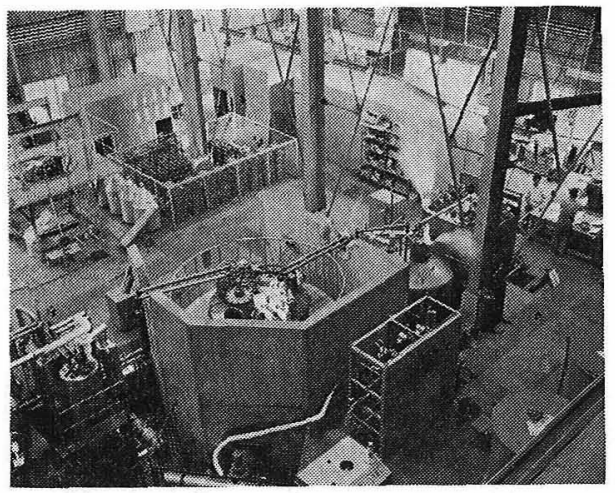

Fig. 14 Bird's-eye view of $45 \mathrm{kG}$ superconducting magnet apparatus.

まで増加し中心磁束密度は最大值 $47 \mathrm{kG}$ を記録した が，コイルには全く異常はなかった。約 1 時間この状 態を保った後で $45 \mathrm{kG}$ まで電流を下げて実験 $\mathrm{E}$ 永久電 流励磁を行なった。

実験 Dでは励磁速度を $11.1 \mathrm{~A} /$ 分と速くして零磁界 から 1 時間17分で定格の $45 \mathrm{kG}$ まで励磁することがで きた。

また本超電導コイルの最大貯蔵エネルギーは $4.5 \times$ $10^{3} \mathrm{~J}$ であった。
磁束密度分布の測定は, 中心磁束密度が $45 \mathrm{kG}$ にな るように励磁電流を固定した状態で行なった。常温空 間中心軸上での磁界分布を Fig. 5 亿実線で示す。も ちろん磁界の向きは MHD 発電に有効な成分 $\mathrm{B}_{y}$ につ いて測定した。この結果磁束密度均一度有効嗞界長 60 $\operatorname{cm}(z= \pm 30 \mathrm{~cm})$ 区閒に㧤いて $95.3 \%$ になり, 有勃 磁界端での磁束密度は $42.8 \mathrm{kG}$ であった。

磁束密度分布測定結果と前に述べた設計計算結果を 比較すると，

（i ）.中心磁束密度と励磁電流の比が設計值に比べ てやや大きくなった。

(ii) 中心軸上の磁束密度分布が計算による分布よ り幅が広かった。

これはコイル形状を Fig. 4 のごとく磁束密度分布 計算用にモデル化する時の直線部と端部の分断の仕方 が大きな原因と思われる。すなわち，実際のコイル形 状では端部と直線部の接続部分は曲線的につながって おり， $\mathrm{B}_{y}$ に寄与する直線部は実效的にはモデルより かなり長い。このために同一コイル電流に対しては中 心磁束密度の計算值は低目に出, また中心点より端部 に近つくにつれて実測值の方が磁束密度がさらに高く なっているものと思われる。

（c） 永久電流励磁（実験項目 $\mathrm{E}$ )

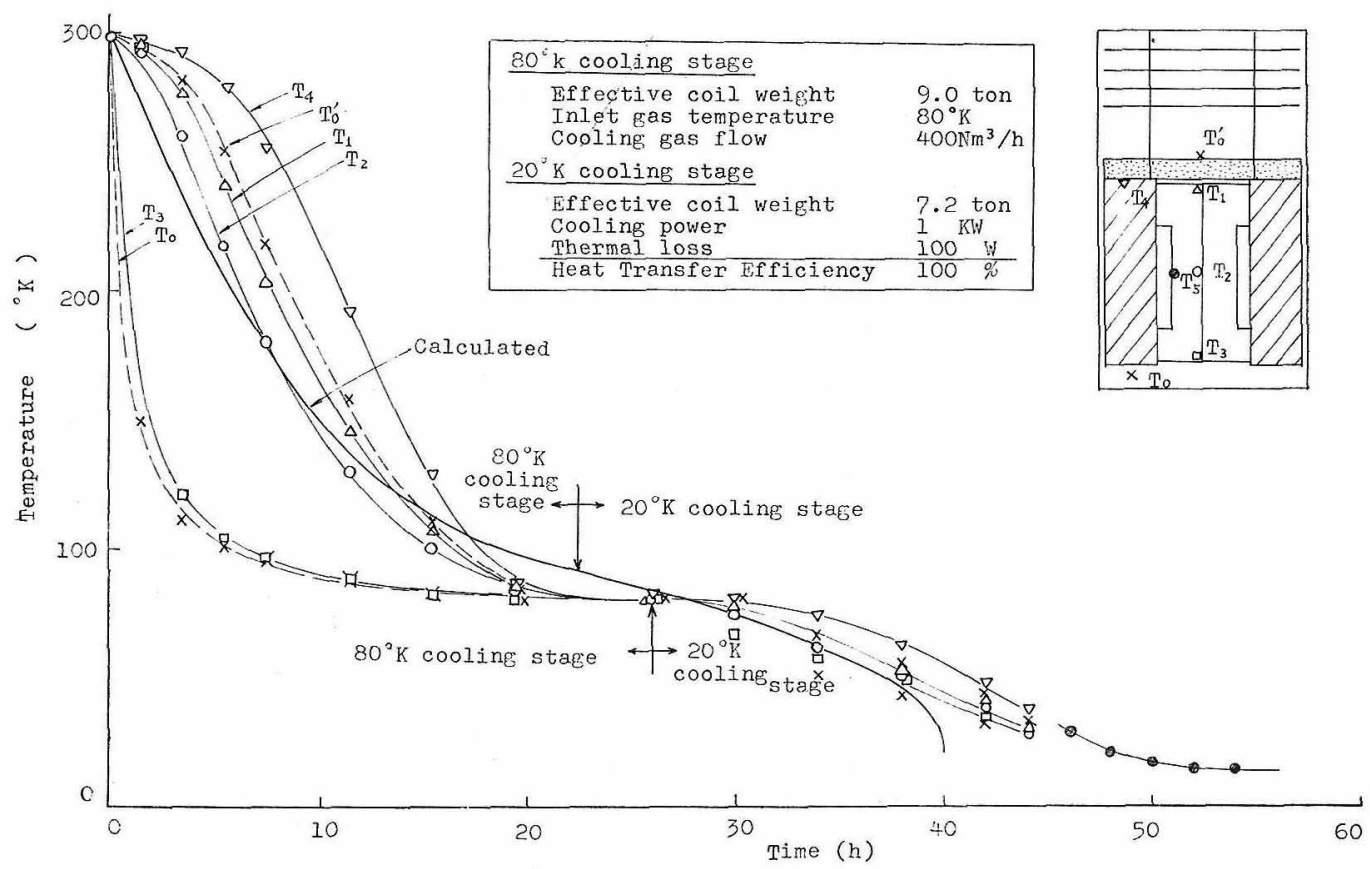

Fig. 15 Cooling down curve. 


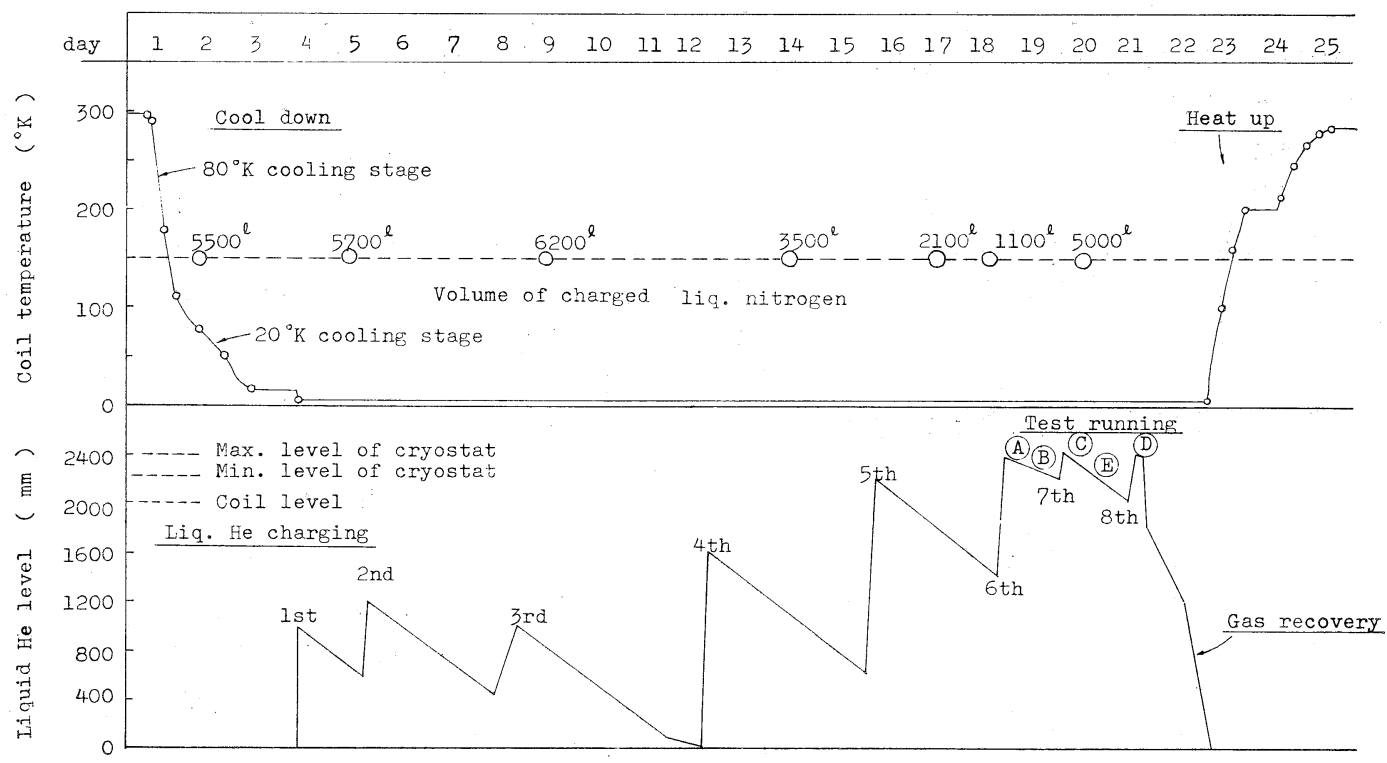

Fig. 16 Process for cooling down and test running.

永久電流励磁実験ではコイル中心磁束密度を $45 \mathrm{kG}$ に設定し, 2 個の永久電流スイッチを閉じた。その後, 電源電流を下げ始めた時点から11時間0.1分たってスイ ッチを開放するまで永久電流を保持した。永久電流励 磁中の磁界変化は, 各部に取り付けたホール素子出力 電圧を常時記録計に記録させるとともに, デジタル電 圧計で 1 時間おきに測定した。

これらの值から算出した永久電流減衰の時定数は, 1,330 時間以上であった。

永久電流減衰の原因となる回路内抵抗分は, 永久電 流スイッチ 2 個の接触抵抗, ストリップと接片の接続 抵抗，ストリップとストリップ間の接続抵抗などがこ とごとく直列に入った場合の全抵抗と考えられ，上記 時定数から算出すると約 $7 \mu \Omega$ になる。この值は設計
目標值の約半分で仕様を十分満足した。

（d）クライオスタットの熱特性（実験項目 A, C, $\mathrm{D}, \mathrm{E}$ )

非通電中の液体へリウム蒸発量は, 液体へリウム最 高液面 (底からの高さ $210 \mathrm{~cm}$ ) から高さ $234 \mathrm{~cm}$ まで 液面の下る時間から平均して求めたもので，定常状態 ではないが実用上の蒸発量を与える。永久電流モード における蒸発量は, 底からの高さ $23.1 \mathrm{~cm}$ から $225 \mathrm{~cm}$ まで液面が下る間で測定した。通電中の蒸発量は, 通 電時間が短く液面降下速度や蒸発ガス流量からの測定 は不可能だったので, 非通電中拉よび永久電流モード におけるデータから推定した。

超電導コイルおよびクライオスタット性能測定值を 目標值とともに Table 3 に示した。

Table 3 Test results and design values

Saddle Shaped Coil

Central magnetic field

Field uniformity $(10 \mathrm{~cm} \times 60 \mathrm{cmL})$

Current decay time-constant

(Persistent mode)

$\begin{array}{cc}\text { Test Results } & \text { Design Values } \\ 47 \mathrm{kG} & 46 \mathrm{kG} \\ 95 \% & >89 \% \\ >1,300 \text { hours } & >720 \text { hours }\end{array}$

Cryostat (Boil-off rate of liquid helium)

With magnet not energized

$10 \mathrm{l} / \mathrm{h}$

$11 \mathrm{l} / \mathrm{h}$

$11 \sim 13 l / \mathrm{h}$

$16 l / \mathrm{h}$

$12 \mathrm{l} / \mathrm{h}$ 
Table 3 からも分かるように，クライオスタットの 熱特性は総合的には目標値よりやや良好であった。侵 入熱の個々の経路を分析することはかなり難しいが, 非通電時について 3.2 で述べた設計値の内容と比較す ると, 傾向としてはパワーリードの侵入熱は増加し, 輻射による侵入熱は減少, 伝導による侵入熱はほぼ設 計值に近かったものと推定される。パワーリードの侵 入熱の増加は通電時の性能を重視して材質を変えたこ とに原因があり，輻射による侵入熱の減少は輻射面の 輻射能を設計值よりも小さくできたことによる。

\section{6. 結 言}

本試作研究によって完成した $45 \mathrm{kG}$ 超電導電磁石 は, 鞍形超電導マグネットとしてこれまで世界最大で あった AVCO 社のもの (内径 $30.5 \mathrm{~cm}$, 中心磁束密 度 $37 \mathrm{kG}$ ，貯蔵エネルギー $3.9 \mathrm{MJ}$ ) を抜いた世界最 大の規模のものである。これを超電導材料を含めてす ベて国産品で製作しその運転試験に成功したことによ り，わが国における大型超電導マグネットの設計, 製 作, 計測, 運転等の技術的基盤は確立されたものと考
える。今後さらに大型, 高磁界の各種超電導マグネッ トが建設され，MHD 発電機をはじめ原子核実験用, 核融合装置用, あるいは超高速列車浮上用等の応用分 野が開拓されることを期待したい。

終りに本研究を遂行するに当り種々ご指導いただい た電気試験所森所長, 伏見機器部長, 日大安河内教授, 東大関口教授, 東工大森教授, また特に総合運転試験 についてご指導, ご協力いただいた超電導研究室等々 力室長をはじめ同研究室の方々に厚く扔礼申し上げま す。

\section{参 考 文 献}

1）土井, 大原, 他.. 日本特許 No. 507097 .

2) Z. J. J. Stekly et al. : IEEE Trans. on Nuclear Science NS-12 (1965) 367.

A. R. Kantrowitz et al. : Appl. Phys. Lett. 6 (1965) 56.

3) 尾形, 剣持, 他: 低温工学 4 (1969) 219.

4) 川辺, 七里 : 第 5 回低温工学発表会 (1969) S-2. 